\title{
Hero and Villain on a Foreign Land: A Textual Analysis on U.S. Newspaper Coverage of China's Uighur Unrest
}

\author{
Di Zhu ${ }^{1, *}$ \\ ${ }^{1}$ School of Journalism, University of Missouri, 65211, Columbia, Missouri, United States
}

\begin{abstract}
This study aims at understanding U.S. media coverage of China's relationship with its mostly Muslim minority group Uighur during the period of several deadly attacks conducted by members from Uighur ethnic group. The study looks into 52 news stories and 3 opinion pieces in the New York Times and the Washington Post in a six-month period. Drawn from the theories of news framing and news narratives, the analysis found that the news discourse about China's Uighur unrest presented a clear-cut vision of a repressive government and a prisoned intellectual Ilham Tohti. This image conjures two major mythical elements: the repressive villain and the persecuted hero. By attributing the ultimate blame unanimously to government control and policy, the articles employed a resentment frame to portray China's ethnic relationships and downplayed the severity of actual attacks.
\end{abstract}

\section{Introduction}

Humans seek to comprehend and make sense of individual events, including tragedies in our world. News, as one major source of public knowledge, provides us with narratives and helps construct a social reality that is coherent and meaningful $[1,2]$. International news, in particular, opens a window for people to understand things that happened on the other side of the world. They might be the only source for people to learn about the political institutions and social conflicts that are different from their own. At the same time, journalism, as an "authored text" [1] is never free from values. Journalists embed individual facts into bigger frames and use storytelling techniques to pass on assumptions, attitudes and values.

Two different lines of theoretical development and empirical studies, namely, news framing and news narrative studies, focus on these underlying elements of news and try to explain how journalists use consistent themes, frames, myth and archetypes to diagnose causes and provide moral reasoning $[3,4,5,6]$. Although framings and narratives research come from different intellectual lineage, they both offered lenses to examine the power of

* Corresponding author: dz78d@mail.missouri.edu 
journalism to give meanings, pass on values and provide moral judgments. In this sense, they could be used together to understand news portrayal of international events and offer an insightful account of ethnicity, conflicts and politics, because international reporting often requires journalists to provide more contexts and explanations. This study tries to combine theoretical contributions of news framing and news narrative research with an analysis of the coverage of deadly attacks conducted by ethnic minority groups in China.

In the year of 2014, several deadly attacks conducted by people from Uighur ethnic minority group in China have drawn international attention. Among them, the Kunming Train Station mass stabbing in March left more than 30 innocent passengers dead and more than 140 injured. In May 40 civilians were killed ruthlessly in a market attack in the capital city of Xinjiang Province. Following attacks happened in rural areas of Xinjiang province later, and the two most deadly ones happened in the county of Shache and Luntai, where groups of attackers started with assaulting government offices and police stations, and both Uighur attackers and civilians were killed in these clashes. Uighur is one of China's 55 ethnical minority groups, and most of its people live in the country's northwestern province Xinjiang and practice the religion of Sunni Islam.

Chinese government and media called these attacks terrorist attacks incited by separatism forces while the U.S. news coverage of these incidents and China's relationship with its ethnical minorities paints a different picture. Scholars have argued that news discourse often does not and cannot capture an objective reality. Instead, it highlights certain aspects of an issue and downplays others by employing frames and telling tales [3, 7, 8]. U.S. newspaper coverage of these attacks and why they happened can reflect and confirm not only the nature of these events, but also the values and beliefs that are consistent with a shared reality about China in the American public.

This article studied the New York Times and the Washington Post's coverage of Uighur groups against the background of the unrest and terrorist attacks. The article will first trace out how terrorist and terrorism were often portrayed and how issues about China were discussed in U.S. media. The concept of news myth and news framing were adopted to analyze important events under each category. Then the fifty-five news stories and opinion pieces on the Uighur attacks will be examined in a textual analysis to explore how the story of terror in China were framed and retold in U.S. mainstream media.

\section{Literature Review}

\subsection{Media coverage of Muslim group and terrorism}

Previous studies on U.S. media's coverage on Muslim groups found that news media tend to quickly associate terrorism with Muslim and Islam and feed a narrative emphasizing fear and violence after the terrorist attacks of $9 / 11[9,10]$. This negative association in media magnified the reality of "Islamic extremism" and reinforced an Orientalism ideology that widened the divide between "Self (Western world)" and "Others (So called Orient that are different from Western world)" [11, 12].

One way to look at this misrepresentation of terrorism is the framing theory. News media constantly employ "frames" to tell stories and making sense of complicated events. Scholars argue that news frame works as an interpretive structure and help journalists 
identify problems, assign values and provide solutions [13]. Intentionally or unintentionally, news writers emphasize certain aspects of the issue while excluding other factors that they consider irrelevant or less important. The coverage of international tragic events like terrorist attacks often adopted a frame that is consistent with U.S. foreign policy or administrative stand. Certain policy catchphrase invented by government administration, such as the "War on Terror" label, can be internalized by journalists in their daily discourse, reified as an uncontested thing and naturalized as a taken-for-granted worldview in the news coverage [14].

As media become an integral part of American politics, journalists adopt the language and perspective of the political establishment, particularly in foreign affairs coverage Sometimes the news coverage can in turn influence politics. Entman examined U.S. media coverage of the shooting down of two passenger planes in 1980s, one shot down by a Soviet fight plane, another shot done by a U.S. Navy ship, and found that U.S. media outlets employed different frames in telling the stories [4]. By eliciting moral evaluations in the former story and framing the later one as a technical accident, these two kinds of frames reinforced and strengthened public belief of "Soviet's moral guilt" and legitimized U.S. military policies in the Gulf [4].

The way news stories are structured and produced can also be understood through the perspective of myth. Myth exists in journalists' storytelling traditions and underlies and sustains certain ideologies and social values [8]. Bird and Dardenne [3] believed the journalistic use of myth, the illusion to heroes, villains, scapegoats and archetypal principles and figures, has a function of explaining and comforting. They argued that, "one function of myth is to explain which cannot be easily explained [...] as well as more intangible things, such as notions of morality, appropriateness and fairness. This [...] was a function of people's intolerance for randomness, inexplicability and ambiguity. [3]" U.S. media have constantly resorted to myths to make sense of traumatic events in its own history. Lule [8] studied the major myths used in the New York Times editorials after the September 11th terrorist attack. He pointed out that the allusion to shattered innocence, the victims, the heroes and the anxiety about future constructed a strategy to proclaim and sustain social order. Berkowitz [15] explored the mythical narratives in news stories and opinion pieces after the Virginia Tech shooting and found that the reference to the Holocaust and the allusion to an ironic hero who survived the Holocaust but died in the shooting attack have served a function in the public healing process.

Most of existing studies on Muslim and terrorist attacks focused on the narrative of incidents happened on the soil of U.S., where there are major tensions between American people and Muslim individuals (or groups). U.S. news discourse on Muslim in other countries might adopt a different strategy. The present research looked into several disastrous attacks happened in China and explored how U.S. media employ frames and myth in making sense of a terrible event that happened outside United States.

\subsection{Media coverage of China}

An analysis of U.S. media coverage of attacks happened in China cannot overlook the important tradition of how China was often portrayed in U.S. news discourse. U.S. media coverage of issues in China have been found to be related to the international relations between the two countries and U.S. foreign policy at different times [16, 17, 18]. Retzinger and Scheff [19] pointed out that a country's ideology both produce and is produced by the narrative that it tells to itself and the others about conflicts. Therefore, a look into the news rhetoric about China cannot be fully understood without acknowledging the two countries political, economical and ideological differences and competition. U.S. International Relation theorists argues that China's growing capabilities has become a potential threat for 
U.S. economy and in the competition for global powers [20, 21]. Pan [22] proposed that the "China threat" literatures are "not value-free, objective descriptions of an independent, preexisting Chinese reality out there, but are better understood as a kind of normative, meaning-giving practice that often legitimates power politics in U.S.-China relations and helps transform the "China threat' into social reality."

Turner [23] conducted case studies on the representations of China in different historical periods and showed that the image of a dangerous China helps reaffirm U.S. identity from time to time. Their studies on IR literatures suggest a myth of "China threat" that was imagined by U.S. politicians and scholars and legitimized U.S. ideology as universal and indispensable. Compared to international relation study literature and political speeches, news media play an even more important role in constructing reality for American public and reinforcing the ideology and moral values of U.S. political system in the world. Therefore, the rhetoric of an internationally influential elite media such as the New York Times and the Washington Post can be seen as a relatively subtle, powerful and natural way to influence public beliefs and values. Therefore, the ways that this article addresses and implies about China's policy and ideology will be another focus of this study.

Besides these studies on International Relations literature, scholars also studied the U.S. news discourse on several important events in China and argued that media framing and invocation of these singular incidents should be seen as a representative part of the overall media framing about China [24, 25]. Lee et al. [26] examined New York Times and Washington Post's editorial use of and reference to the 1989 Tiananmen protests and its crackdown as a "news icon" over a period of 20 years and found that this event was initially used as a powerful symbol of totalitarian dictatorship in China, then becomes a symbol of China's human rights violation in 1990s, and at last turn into a less-powerful ritualistic memory of China's repression in news editorials. Another analysis of media frames employed on reporting the Hong Kong's reunification with China in 1997 found that the coverage of the event can be summarized into ideological packages that projected Hong Kong's loss of freedom under Chinese rule and its potential role as a "Trojan horse" to spread political and economic changes in China [27].

The previous researches on media coverage of both terrorism and China have informed the coding and analysis of this study. The present study thus asked two general research questions: 1). How were the Uighur attacks and violence in China framed in U.S. mainstream media? 2). To view all the news stories and opinion pieces on this issue as integral parts of a constructed reality, how was blame and responsibility attributed and the hero identified in the form of myth? A textual analysis will be used to answer these research questions.

\section{Methodology}

This study examined 52 news stories and 3 editorial pieces on the New York Times and the Washington Post about the relationship between Chinese government and Uighur minority during the period of the four most deadly Uighur attacks in 2014 (from the first attack in March 1st to one week after the fourth attack on September 21st). Both the New York Times and the Washington Post have long been regarded as the most influential national newspapers that influences and represents U.S. foreign policies and set the political agenda for public issues $[28,29,30]$. Therefore, their coverage of China and its ethnic conflicts can be seen as an indication of U.S. foreign policy toward China and a reflection of the public narrative about China in the mass media.

The search term "Xinjiang" and "Uighur" are used together to find as many related articles as possible and yielded a result of 99 stories in total. The researcher then went through every article and eliminated all the articles that is not related to the attacks or 
violence. Words like "unrest," "tension," "clashes" and "violence" were all considered as an allusion to the attacks; articles with these words were thus included in the final group of articles.

The texts were then analyzed with a coding sheet designed both deductively and inductively (See Appendix A). Questions such as "Did the article use a thematic or episodic frame to describe the attack(s)," and "How was the blame of the attack(s) attributed?" were drawn from the framing theory literature [7,31]. Questions such as "Who was identified as the villain in this article?" "Is there a hero in the story, how was he/she described?" were drawn from the news myth literature $[3,8,15]$. Quotations in all the articles were closely examined, too, as journalists also constantly filter their sources and make decisions on whom to quote. Quotations, as well as background information provided in a story, help build the theme and support a point a view in news stories [31]. Due to the specific subject of this study, the coding sheet also inductively include items about the image of Uighur people, the image of Xinjiang region, the label of the attacks (whether it used the label of terrorist attacks or not) and the phrase used to describe the relationship between Chinese government and Uighur minority group to fully capture the constructed reality about the violence, the hero and an "repressive" China in U.S. media.

Because one person coded all the selected articles based on the code sheet, the study examined individual words and phrases to ensure that the data were analyzed rigorously. Representative wordings in the article are also presented in the analysis to ensure transparency. For example, to code for the question concerning villains in the article, the researcher looked for specific phrases that directs blame or depicts an oppressive power. Sentences and words that are ambiguous are not included in the analysis.

\section{Analysis}

The articles in New York Times and the Washington Post covered a variety of aspects in the unrest. The themes of the articles ranged from the attacks themselves, Chinese government's response toward the attacks, feature stories about the region's Xinjiang and Uighur minority groups, the arrest and trial of suspects, and interestingly, the arrest and trial of a Uighur scholar Ilham Tohti. Out of 55 articles, only 15 focused on the violent acts themselves. And even in the article that talks about individual attack, the journalist tend to adopt a thematic frame instead of an episodic frame to discuss the causes and background information. Violent attacks in China and Uighur minority groups are both distant and unfamiliar concepts to most of American readers, therefore it is necessary for the journalists to provide some context to make sense of the incidents and help readers understand potential factors of the crime. In this sense, most of the articles offered some explanation on the attacks and its consequences. A detailed description of the myths and frames used in these explanations will be discussed as followed.

\subsection{The Repressive Villain}

In a majority of the news stories and opinion pieces, the blame of violence and unrest is partially or fully attributed to the policies of Chinese government or the Communist party. A picture of an oppressive central government is the repeating theme in all the stories. The unrest was described as "an inevitable result of Beijing's continued repression" ("Pushing the Uighurs too far," NYT, March 19). Some articles even put it more openly, saying, "The escalation of violence is the direct result of China's repression" ("The Price of China's Repression," NYT, September 26). China's policies were often described as "Beijing's iron rule" or "Beijing's heavy-handed tactics" in a lot of articles, while Uighur people were depicted as victims "chafed under Chinese rule" ("Ethnic Tension in China's Xinjiang 
Province," WP, March 3) and "backed into a corner by Beijing's relentless antagonizing tactics" ("Pushing the Uighurs too far," NYT, March 19). Even in articles that tried to show two sides of the arguments, as Chinese government blame the attacks on Islam extremists while Uighur exile groups blame them to Chinese government's crackdown, the Chinese official's accounts were always put into less important position and called into question later with an indication that there's something more severe and scary than the recent deadly attacks on civilians:

Chinese authorities described the mass slaughter as a "premeditated, violent terrorist attack" perpetuated by separatists from Xinjiang. [...] Clashes over the past year have claimed more than 100 lives, many of them Uighurs killed by security forces during what officials describe as terrorist attacks. Uighur exile groups blame for the bloodshed on paramilitary police officers they say have been given the green light to use deadly force against unarmed protest. ("China Remodels an Ancient Silk Road City, and an Ethnic Rift Widens, "NYT, March 6)

It is interesting to note that the government account of the attacks were always put in quotation marks while the Uighur groups and Western experts' point of view were often presented without a quotation mark. In this way, the reporters kept their distance from whatever Chinese government and media says about the attacks and legitimize the narrative from Uighur exile groups.

Related to this issue is the emphasis on China's propaganda efforts, which suggest a deceitful agenda behind all the investigation and responses to the attacks. In all of the articles, the blame to the separatist (or terrorist) groups was always immediately followed by "says government-run Xinhua News Agency" or "according to a government-run website." In this way, the intricate relations between Chinese government and any media outlet were always identified openly. However, the background of other sources, such as the Radio Free Asia (a U.S. government funded radio station), was not explained.

Furthermore, lengthy descriptions about Chinese government's propaganda schemes become a recurring context in a lot of the articles. Some stories went in-depth about the specific propagandas the government has executed: "the state media showcased a new 'harmonious village' where the two ethnicities would live side by side" ("Uighur Scholar's Life Sentence is Seen as China's Effort to Stifle Debate on Minorities," NYT, September 25). Chinese government's efforts to educate Uighur women and provide them with training classes were described as "Beijing has spent heavily wooing women in Xinjiang" and "cheerful propaganda" ("Veils Emerge as Sign of Uighur Protest in China," NYT, August 8).

One of the New York Times article devoted all its content on how "party-run history machine" made up historical stories from the real cause of country's disastrous famine to the blaming of United States for starting the Korean War. It summarized, "China's Communist Party has devoted enormous resources to composing historical narratives that seek to legitimize its rule and obfuscate its failure" ("In China, Myth of Social Cohesion," NYT, August 19).

By identifying most of the governmental policies and programs as propaganda and making the propaganda as the most salient background of the attacks and unrest, these news coverage and editorials discredit explanations made by Chinese government and suggest that the repression and propaganda is something more important and more horrible than attackers killing innocent people on the street. And the attacks were just an extreme form of "Uighurs resistance to rule by Han majority."

Although some of the articles did mention an "Islamist militant group" blamed by the Chinese government for the attacks, but the author always went back to blame Chinese government's suppression as the ultimate explanation for all the violence. For example, in one of the Washington Post article that focused on the jihadist threat posed by Uighur 
extremists, the author spent the first half of the articles talking about how U.S. and China might have a common interest in cooperation against militant from Islamic State, and then spent the second half of the article condemning China's domestic policy:

But China's focus on the external threat inspiration for some of the violence in Xinjiang is missing the bigger picture, experts say. The long-running and brutal suppression of Uighur rights, culture and nationalist sentiment has bred deep resentment here while an intensified campaign to educate people by turning them away from Islam - preventing women from wearing veils and students from attending mosques for example - seems to have caused even more anger ("China Faces Jihadist Threat at Home and Abroad," WP, September 8).

In sum, most of the articles employed a frame of repression and fear in the coverage over the course of six month in between these four attacks. Interestingly, the fear is not directed towards the attackers (if not terrorists), in fact, the attacks were often used merely as a background to the portrayal of China's ruthless domestic policies and silencing of dissidents. The narrative of most of the articles identified a bigger source of fear, a villain government, who carried out crackdowns, surveillance and propaganda, a villain who pursued economic and political policies that were unfair to its minority. And this villain is the real cause for all the resentment that leads to violence.

\subsection{The Imprisoned Hero}

The hero in this narrative is, naturally, the oppressed. But he is not any kind of Uighur under government surveillance and control. The hero, Ilham Tohti, is the intelligent and politically active scholar who was found guilty of "inciting ethnical separatist" and prisoned by the Chinese government. Most of the articles identified Ilham Tohti as a "Uighur economist" or "the most prominent Uighur scholar," which give him a sense of intellectual credibility of speaking out for Uighurs and calling for political changes. $\mathrm{He}$ taught economics at the Central University of Nationalities and had a website that tried to encourage communication between Uighur and Han people; the latter is the majority ethnical group in China. He was arrested in January for inciting students to violence. Tohti is a recurring character in most of the articles, not only in the fourteen articles that focused on his trial and conviction. His name is also frequently mentioned in other articles that talk about the attacks and governments' strategies to tamp down the violence as an archetypal figure of the victim under government repression.

The news stories described his careers and works as "building bridges between Han Chinese and Uighurs" and "a model of moderation." By portraying him as a bridge builder and moderate dissident who does not want to do any harm to the unity of China, the repressive villains' allegation and strategy seems even more irrational and outrageous: "The sentence [of Ilham Tohti] is a sign of confusion and desperation behind the governments' policies toward Uighurs" ("Fruitless Repression," NYT, September 29). The articles that focused on his trial and sentence also consistently gave Tohti benefit of doubt by devoting a majority of their content quoting his layer, wife and his daughter who studied in United States. Foreign experts and groups were also frequently quoted to condemn China's unfair treatment and support Tohti's innocence, while the actual charges against him were often accompanied by the word "reportedly."

In addition, the situation of Tohti's imprisonment was described in detail with similar structures across publications. Articles in both the New York Times and the Washington Post talked about him being shackled, his hunger strike, and how prison officials have refused him food in the following days. To this point, the news discourse further changed the direction of attention from attackers' constant mass slaughtering during these six months to the dreadful accusation of a single intellectual by the repressive government. 


\subsection{The Attacks and the people as a backdrop}

As mentioned earlier, brutal attacks were not the focus in most of the articles and were used just as a background to discuss other issues. Sometimes they were mentioned as a lead to the criticism of China's "anti-terrorism steps;" other times they were brought up to explain Ilham Tohti's arrest. In one of the articles that focused on Ilham Tohti's imprisonment, the whole article only mentioned one attack once (the Kunming train station deadly stabbing) at the end of one sentence:

[Ilham Tohti] went on a hunger strike in January for 10 days because his food was not halal prepared according to Muslim religious traditions - and was denied food by prison authorities for a similar period after Uighur separatists carried out a deadly knife attack in the city of Kunming in March ("Uighur Scholar Faces Chinese Trial that Critics Say Highlights Repression," WP, September 17).

In fact, during this period of six months, and out of 55 articles, only 15 news stories were talking about specific attacks. The rest of the articles gave the attacks a secondary role and a majority of them rejected the label of terrorist attacks. The incidents were called "big, bloody race riot," "a deadly wave of ethnic violence," "mass slaughter," "train station rampage." The description of the attacks and the restive situation still invokes fear, but by dissociating them from terrorism, the responsibility of the violence were wholly attributed to bad government policies.

The attacks were also constantly associated with the label "protests" and framed as a response to political repression instead of malicious sabotage. This kind of frame can be best summarized in one article, the reporter claimed, "their protests are a reaction" ("Clashes, anti-terrorism steps worsen China's Uighur Ties," WP, May 11). Another article went back to an earlier attack in 2009 and elaborated the course of events in detail: "after a heavy-handed police response, the protests spiraled into ethnic bloodletting, claiming nearly 200 lives, most of them Han"("Chinese Officials Seek to Shift Attention From Rampage," NYT, March 5). The attacks and violence, according to the news narratives, becomes some kind of last resort and a side effect of peaceful protests for a just political cause.

Besides the backdrop of constant violence, these articles' depiction of the relationship between Chinese government and Uighur minority groups focused on a frame of resentment and fragmentation. The word "resentment" and "hatred" were used frequently when talking about Uighur people's attitudes toward both central government and the majority Han people. The articles also suggested a fundamental divide instead of cohesion between Uighur minority groups and the rest of the country: "Xinjiang, rich in resources and strategically important, lies on the borders of Central Asia and is home to the mainly Muslim Uighurs, who speak a Turkic language and are culturally distinct from China's ethnic Han majority" ("Market Attack Kills 31 in Far Western China," WP, May 23). Similar depiction of Xinjiang and Uighur people appears again and again in articles to make the cultural, linguistic and religious divergence between Uighur and Han the most salient characteristic of the region and the people.

The background information about Xinjiang as an "ethnically divided region that has been convulsed by mounting violence" and about the Uighur-Han relations as "an ethnic rift" seems to suggest that the region and the people have irreconcilable differences with the rest of the country. This narrative downplays any similarities, friendships and cooperation and domestic unity among different ethnical groups or discredits them as government propaganda. In this way, the call for independence and "autonomy" were legitimized and the strategies to identify and restrict separatist forces were portrayed as a sign of intrusion and outside repression. 


\section{Discussion}

This study present the stories told in the New York Times and Washington Post presented about China's Uighur unrest. These stories offered a clear-cut vision of a repressive government and a prisoned intellectual Ilham Tohti. The depiction conjures two major myth elements: the repressive villain and the persecuted hero. By attributing the ultimate blame unanimously to government control, unfair policies and even the problematic political system, these articles framed the attacks as unpreventable tragedies caused by the government's repression. The attackers' role as villain was blurred and downplayed; China's crackdown on what they believed as terrorist movement was so severe and inhumane that it surpassed the priority of covering the actual events. Even in the actual coverage of singular events, to understand the cruel tragedies happened in another country, U.S. media resorted to myth to make sense of the event, and by portraying China as an authoritarian society under moral scrutiny of U.S. democratic standards, the villain myth also helped U.S. to distance itself from this kind of tragedy. This finding is consistent with what Lee et al. [26] found in their study about how U.S. mainstream media has associated the Tiananmen as a symbolic reference to an Authoritarian government and its human rights abuses. The coverage of the Uighur unrest reinforces and reuses this already constructed image of a repressive China and its human rights problems.

In addition, the articles also employ a frame of fear and resentment in its coverage of the relationship between Uighur groups and the Han-dominated government. The narrative indicates a hostile situation among all the groups in Xinjiang and project a future of dreadful backslash and more severe clashes. At last, different from the common negative portrayal of Muslim people in U.S. media, the image of the Muslim Uighur are depicted in a sympathetic light as they, as an entire ethnic group, undergone the heavy-handed repression of Chinese government. An intellectual from Uighur group, Ilham Tohti, were given great attention in the coverage and his argument about the unfair economic and political conditions of Uighurs were reiterated in a lot of articles. This positive and sympathetic depiction of Uighur people's life and their marginalization as a minority group provided counter narrative for Muslim groups in U.S. media.

The conventional frames adopted in U.S. media's coverage of terrorism often provided a one-sided context that make one simple explanation seem natural and render contradictory interpretations hard to fit into the preexisting viewpoint $[32,33]$. The finding of this study suggests that there could be alternative frames in covering violent attacks. By empathizing with Muslim minorities who faced economic and political predicament and individuals who were imprisoned by government due to national security reasons, the news media can provide a better platform for multiple communities to express the meaning and interpretation of similar events.

The authors of these articles from time to time employed different frames in their arguments. For example, one article in the New York Times pointed out in the end that, "management of diversity and pluralism is a pressing world issue, from Scotland, Ukarine to Ferguson, Mo" ("Fruitless Repression," NYT, September 29). To see the problem from an international perspective and to compare it with other similarly complicated issues, even problems facing United States itself, is to veer away from targeting a single villain and ignoring other aspects of the factors that caused violence. However, most of the times, even in this editorial piece, the author came back to imposing an U.S. dominant ideological to evaluate foreign issues.

This study has several limitations. First, it only analyzed U.S. mainstream newspapers' coverage of Uighur attacks happened in China. Future studies could use a comparative method to see if there are differences between the coverage of attacks conducted by minority groups in China and attacks happened in U.S. or other Western countries. This 
study of the New York Times and the Washington Post coverage of foreign issues also raise further questions on how it corresponds with U.S. foreign policy or how it can influence public opinion. A more detailed study that combined an examination of Sino-U.S. relationships and with the media coverage of attacks (the earliest deadly attack started from 2009) over the years can be conducted to investigate this relationship.

\section{References}

1. B. McNair, The sociology of journalism. New York, NY: Arnold. (1998)

2. M. Schudson, The power of news. Cambridge, Mass: Harvard University Press. (1996)

3. S.E. Bird, R.W. Dardenne Bird, Myth, chronicle, and story: Exploring the narrative qualities of news. In J. W. Carey (Ed.), Media, myth and narratives. Beverly Hills,CA: Sage. (1988)

4. R.M. Entman, Framing U.S. coverage of international news: Contrasts in narratives of the KAL and Iran air incidents. J. Commun. 41, 4, 6-27 (1991)

5. W. A. Gamson, A. Modigliani, Media Discourse and Public Opinion on Nuclear Power: A Constructionist Approach. AJS 95, 1, 1 (1989)

6. S. Hall, The narrative construction of reality: An interview with Stuart Hall. S. Rev. 17: 3-17 (1984)

7. R. M. Entman, Framing: toward clarification of a fractured paradigm. J. Commun. 43, 4: 51-58 (1993)

8. J. Lule, Myth and Terror on the Editorial Page: The New York Times Responds to September 11, 2001. JRMC 79, 2, 275-293 (2002)

9. K. A. Powell, Framing Islam: an analysis of U.S. media coverage of Terrorism since 9/11, Commun. Stud. 62, 1, 90-112 (2011)

10. P. Morey, Y. Amina, Framing Muslims: Stereotyping and Representation after 9/11. Cambridge, Mass: Harvard University Press. (2011)

11. E. W. Said, Covering Islam. New York, NY: Pantheon Books. (1981)

12. H. K. Karim, Islamic peril: Media and global violence. New York, NY: Black Rose Books. (2000)

13. R. M. Entman, J. Matthers, L. Pellicano, Nature, sources and effects of news framing, in Karin Wahl-Jorgensen \& Thomas Hanitzsch (ed.) Handbook of Journalism Studies. New York, NY: Routledge. (2009)

14. S. C. Lewis, S. D. Reese, What is the War on Terror? Framing through the Eyes of Journalists. Journalism Mass Comm. 86, 1, 85-102 (2009).

15. D. Berkowitz, The Ironic Hero of Virginia Tech: Healing Trauma through Mythical Narrative and Collective Memory. Journalism. 11, 6, 643-59 (2010)

16. T. K. Chang, The impact of presidential statements on press editorials regarding U.S.China Policy, 1950-1984. Commun. Res. 16, 4, 486-509 (1989)

17. Y. Yu, D. Riffe, Chiang and Mao in U.S. news magazines. Journalism Quart. 66, 913914 (1988)

18. Z. Peng, Representation of China: An across time analysis of coverage in the New York Times and Los Angeles Times. Asian J. Commun. 14, 1, 53-67 (2004)

19. S. Retzinger, T. Scheff, Emotion, alienation, and narratives: Resolving intractable conflict. Mediation Quart. 18, 1, 71-85. (2000)

20. H. Harding, The concept of "Greater China": Themes, variations and reservations, in David Shambaugh (Ed.) Greater China: The next superpower? 31-50 Oxford: Oxford University Press. (1995)

21. D. Roy, Rising China and U.S. interests: Inevitable vs. Contingent hazards," Orbis 47. 1, 130-151 (2003) 
22. C. Pan, The "China Threat" in American Self-Imagination: The Discursive Construction of Other as Power Politics, Alternatives: Global, Local, Political 29, 3, 305-331 (2004)

23. O. Turner, "Threatening" China and US security: the international politics of identity. Rev. Int. Stud. 39, 4, 903-924 (2013)

24. G. C. Stone, Z. Xiao, Anointing a New Enemy: The Rise of Anti-China Coverage after the USSR's Demise. Int. Commun. Gazette 69, 1, 91-108 (2007)

25. C.-C. Lee, Established Pluralism: US Elite Media Discourse about China Policy. Journalism Stud. 3, 3, 343-57 (2002)

26. C.-C. Lee, H. Li, F. L. Lee, Symbolic Use of Decisive Events: Tiananmen as a News Icon in the editorials of the elite U.S. press. Int. J. Press/Politics, 16, 3, 335-356 (2011)

27. C.-C. Lee, Z. Pan, J. M. Chan, C. Y. K. So, Through the eyes of U.S. media: banging the democracy drum in Hong Kong. J. Commun. 51, 2, 345-365 (2001)

28. S. Hess, International News and Foreign Correspondence. Washington: Brookings. (1996)

29. D. Graber, Mass Media and American Politics. Washington: Congressional Quarterly Press. (1997)

30. H. J. Gans, Deciding What's News. New York: Pantheon. (1979)

31. Z. Pan, G. M. Kosicki, Framing analysis: an approach to news discourse. Polit. Commun. 10, 55-75 (1993)

32. K. S. Johnson-Cartee, News narratives and news framing: constructing political reality. Lanham: Rowman \& Littlefield Publishers. (2006)

33. S. Iyengar, Is Anyone Responsible? How Television Frames Political Issues? Chicago, IL: University of Chicago Press. ( 1991) 